\title{
Common variants of a urate-associated gene $L R P 2$ are not associated with gout susceptibility
}

\author{
Akiyoshi Nakayama $\cdot$ Hirotaka Matsuo $\cdot$ Toru Shimizu $\cdot$ Yuzo Takada \\ Takahiro Nakamura $\cdot$ Seiko Shimizu $\cdot$ Toshinori Chiba $\cdot$ Masayuki Sakiyama $\cdot$ \\ Mariko Naito $\cdot$ Emi Morita $\cdot$ Kimiyoshi Ichida $\cdot$ Nariyoshi Shinomiya
}

Received: 21 September 2013 / Accepted: 14 December 2013 / Published online: 24 December 2013

(C) The Author(s) 2013. This article is published with open access at Springerlink.com

\begin{abstract}
A recent genome-wide association study revealed that there is an association between serum uric acid (SUA) levels and rs2544390, a common variant in lowdensity lipoprotein-related protein 2 (LRP2/Megalin) gene. Two other variants of $L R P 2$, rs2229268 and rs3755166, are also found to have associations with dyslipidemia and Alzheimer's disease, respectively, which also could have a relationship with SUA in human. Although no studies report that LRP2 transports urate, LRP2 is a multi-ligand receptor and expresses in many tissues including kidney, suggesting a direct and/or indirect relationship with gout. In the present study, we investigated the association between gout and these variants of $L R P 2$ with 741 clinically diagnosed male gout patients and 1,302 controls. As a result, the three common $L R P 2$ variants, rs2544390, rs2229268 and rs3755166, showed no association with gout $(P=0.76$, 0.55 , and 0.22 , respectively). Our study is the first to reveal
\end{abstract}

Akiyoshi Nakayama and Hirotaka Matsuo have contributed equally to this work.

A. Nakayama $\cdot$ H. Matsuo $(\bowtie) \cdot$ S. Shimizu $\cdot$ T. Chiba

M. Sakiyama $\cdot$ N. Shinomiya

Department of Integrative Physiology and Bio-Nano Medicine,

National Defense Medical College, 3-2 Namiki, Tokorozawa,

Saitama 359-8513, Japan

e-mail: hmatsuo@ndmc.ac.jp

A. Nakayama

Medical Group, Headquarters, Iwo-to Air Base Group,

Japan Air Self-Defense Force, Ogasawara, Japan

T. Shimizu

Midorigaoka Hospital, Takatsuki, Japan

Y. Takada

Laboratory for Biofunctions, The Central Research Institute,

National Defense Medical College, Tokorozawa, Japan that an SUA-related gene $L R P 2$ is not involved in gout susceptibility.

Keywords Gouty arthritis $\cdot$ Hyperuricemia .

Hyperlipidemia · Urate exporter · Low-density lipoprotein receptor (LDLR) · LDLR gene family

\section{Introduction}

Gout is a common disease as a consequence of hyperuricemia. A recent genome-wide association study (GWAS) [1] with 8,868 Japanese revealed the association between serum uric acid (SUA) levels and rs2544390, which is a single nucleotide polymorphism (SNP) in low-density lipoprotein-related protein 2 ( $L R P 2$, also known as Megalin). $L R P 2$ is a member of the low-density lipoprotein receptor [LDLR (MIM606945)] gene family, and two SNPs of $L R P 2$, rs2229268 and rs3755166, are also found to have associations with dyslipidemia [2] and Alzheimer's disease [3],

\author{
T. Nakamura \\ Laboratory for Mathematics, National Defense Medical College, \\ Tokorozawa, Japan \\ M. Naito $\cdot$ E. Morita \\ Department of Preventive Medicine, Graduate School \\ of Medicine, Nagoya University, Nagoya, Japan \\ K. Ichida \\ Department of Internal Medicine, Jikei University School \\ of Medicine, Tokyo, Japan \\ K. Ichida \\ Department of Pathophysiology, Tokyo University of Pharmacy \\ and Life Sciences, Tokyo, Japan
}


Table 1 Association analysis of LRP2 variants, rs2544390, rs2229268, and rs 3755166 in gout patients

\begin{tabular}{|c|c|c|c|c|c|c|c|c|c|c|}
\hline & \multirow[t]{3}{*}{ Chromosomal positions $^{\mathrm{a}}$ (bp) } & \multicolumn{6}{|c|}{ Alleles ${ }^{\mathrm{b}}$} & \multirow[t]{3}{*}{$P$ value } & \multirow[t]{3}{*}{ OR } & \multirow[t]{3}{*}{$95 \% \mathrm{CI}$} \\
\hline & & \multicolumn{3}{|l|}{ Case } & \multicolumn{3}{|c|}{ Control } & & & \\
\hline & & 1 & 2 & MAF & 1 & 2 & MAF & & & \\
\hline rs 2544390 & 170204846 & 747 & 717 & 0.490 & 1,314 & 1,236 & 0.485 & 0.758 & 1.020 & $0.897-1.160$ \\
\hline rs2229268 & 170025083 & 1,051 & 423 & 0.287 & 1,829 & 705 & 0.278 & 0.552 & 1.044 & $0.906-1.204$ \\
\hline rs3755166 & 170219881 & 702 & 778 & 0.474 & 1,277 & 1,307 & 0.494 & 0.223 & 1.083 & $0.953-1.231$ \\
\hline
\end{tabular}

$M A F$ minor allele frequency, $O R$ odds ratio, $C I$ confidence interval

a SNP positions are based on NCBI human genome reference sequence build 37.5. LRP2 is located on chromosome 2q31.1

b The major allele was referred to as allele 1 and the minor allele as 2 . Allele 1 is C and allele 2 is T in rs2544390. Allele 1 is A and allele 2 is $\mathrm{G}$ in rs2229268. Allele 1 is A and allele 2 is $\mathrm{G}$ in rs 3755166

respectively. In this study, we investigated the association between gout and these SNPs with clinically diagnosed gout patients and controls.

\section{Subjects and methods}

\section{Subjects}

All procedures were carried out in accordance with the standards of the institutional ethical committees involved in this project and the Declaration of Helsinki. Written informed consent was obtained from each subject participating in this study. As gout cases, 741 Japanese male individuals were collected from the outpatients of the gout clinics in either Jikei University Hospital (Tokyo, Japan) or Midorigaoka Hospital (Osaka, Japan). All of them were clinically diagnosed with primary gout according to the criteria established by the American College of Rheumatology [4]. As a control group, 1,302 Japanese male individuals with normal SUA $(\leq 7.0 \mathrm{mg} / \mathrm{dl})$ without gout history were collected from the Japan Multi-Institutional Collaborative Cohort Study (J-MICC Study) [5]. The mean age and body-mass index with standard deviation are $55.0 \pm 13.2$ years old and $24.6 \pm 3.5 \mathrm{~kg} / \mathrm{m}^{2}$ for cases, respectively, and $52.7 \pm 8.4$ years old and $23.2 \pm 2.8 \mathrm{~kg} / \mathrm{m}^{2}$ for controls, respectively.

Genetic analysis and statistical analysis

Genomic DNA was extracted from whole peripheral blood cells [6]. Genotyping of rs2544390, rs2229268, and rs3755166 in LRP2 gene was performed by an allelic discrimination assay (Custom Taqman MGB, Applied Biosystems) with a LightCycler 480 (Roche Diagnostics) [7]. To confirm their genotypes, more than 25 samples were subjected to direct sequencing with the following primers: for rs2544390, forward 5'-CTGTCTGAGACCATGACAC AG- $3^{\prime}$ and reverse, 5'-CCTCACCTGTCATTGTCTTG-3'; for 2229268, forward 5'-TCCGTTCAACTTTCAGACAG-3' and reverse $5^{\prime}$-TTCCCAACTTTCTCAGGTTAC- $3^{\prime}$; for 3755166, forward $5^{\prime}$-GTGTAAGGCCACTTGTGC- $3^{\prime}$ and reverse $5^{\prime}$-GAAATGGACGAGGAGGAAAG-3'. DNA sequencing analysis was performed with a 3130xl Genetic Analyzer (Applied Biosystems) [8].

The software R (version 3.0.2) (http://www.r-project.org/) with package GenABEL was used for the calculation of linkage disequilibrium $\left(r^{2}\right)$. For the calculations in the statistical analyses, SPSS v.17.0J (IBM Japan Inc., Tokyo, Japan) was used. The $\chi^{2}$ test was used for association analysis.

\section{Results}

Table 1 shows the alleles of LRP2 variants, rs2544390, rs2229268, and rs3755166, for 2,043 Japanese participants (741 gout cases and 1,302 controls). The call rates for rs2544390, rs3755166, and rs2229268 were 98.2, 98.1, and $99.5 \%$, respectively. $P$ values for Hardy-Weinberg equilibrium of these SNPs were 0.039, 0.095, and 0.134. $P$ values that suggested mistyping were not obtained. The minor allele frequencies (MAFs) for the three $L R P 2$ variants were more than 0.27 in both case and control groups, indicating these SNPs are very common in both these groups. No strong linkage disequilibrium was observed between these three SNPs $\left(r^{2}=0.0014\right.$ between $\mathrm{rs} 2544390$ and rs2229268, $r^{2}=0.0013$ between rs2229268 and rs3755166, $r^{2}=0.15$ between rs 3755166 and rs 2544390 , respectively), showing that these SNPs are independent of each other.

For all gout cases, the association analyses of the three LRP2 variants, rs2544390, rs2229268, and rs3755166, showed no association with gout (Table 1 ).

\section{Discussion}

Our study demonstrated that the three LRP2 variants, rs2544390, rs2229268, and rs3755166, had no association with gout. 
Recent GWAS of SUA $[9,10]$ identified several genes including GLUT9/SLC2A9 and ABCG2/BCRP, which have been revealed to have associations with urate disorders such as renal hypouricemia [11, 12] and gout [13, 14]. Recent reports also show the significance of transporter genes such as ABCG2 [15, 16], NPT1/SLC17A1 [17], MCT9/SLC16A9 [18], and OAT4/SLC22A11 [19], for the pathogenesis of gout. $L R P 2$ was first reported to have the association with SUA in the GWAS by Kamatani et al. [1]. Although we found no studies reporting that LRP2 transports urate, $L R P 2$ variants could have an association with gout risks because gout is a consequence of hyperuricemia. Moreover, it is also demonstrated that LRP2 is a multi-ligand receptor and is expressed in various tissues, mainly in the kidney, especially in glomeruli and proximal tubular cells. As LRP2 has a role of renal reabsorption for its ligands such as insulin [20], LRP2 variants could have an association with SUA variation with increasing insulin resistance.

LRP2 is originally found as a member of the low-density lipoprotein (LDL) receptor family and has been suggested to mediate endocytosis of LDL. Indeed, Mii et al. [2] reported that one variant of $L R P 2$, rs 2229268 , has an association with serum LDL levels in humans, indicating the direct association between $L R P 2$ and LDL. Since dyslipidemia is known as a risk to increase the insulin resistance, rs2229268 seems to have an association with SUA variation. Otherwise, $L R P 2$ could be associated with SUA variation through the endocytosis of urate-binding proteins.

Interestingly, Wang et al. [3] previously reported the association between rs3755166 in LRP2 and Alzheimer's disease in a Chinese population. LRP2, whose ligand ApoE [21] is known for the risk of Alzheimer's disease [22, 23], is expressed in brain and facilitates the clearance of the $\mathrm{A} \beta$ peptide, that is, the cause of Alzheimer's disease [24]. Together with the fact that urate has anti-oxidant effects, LRP2 variants carrying the risk of Alzheimer's disease might have an association with SUA variation.

However, the present study first revealed that the common variants of $L R P 2$ have no association with gout susceptibility. Although $L R P 2$ was first reported to have an association with SUA in Japanese population [1], there are no replication studies indicating an association between $L R P 2$ and SUA in other ancestry such as a European population. It is possible that the present study failed to show these associations due to the limited sample (2,043 individuals). Although further studies of $L R P 2$ are necessary to reveal the relationship between $L R P 2$ variants and gout, our study at least revealed that $L R P 2$ is not a strong genetic risk for gout.

\footnotetext{
Acknowledgments The authors would like to thank all the participants involved in this study. We are indebted to H. Nakashima, J. Abe, K. Gotanda, Y. Morimoto, N. Katsuta, C. Okada, Y. Utsumi, S. Terashige, H. Ogata and H. Inoue, National Defense Medical College, Tokorozawa, Japan for genetic analysis and helpful discussion. This study was
}

supported by grants from the Ministry of Education, Science, and Culture of Japan, the Ministry of Health, Labor and Welfare of Japan, the Ministry of Defense of Japan, the Japan Society for the Promotion of Science, the Kawano Masanori Memorial Foundation for Promotion of Pediatrics, the AstraZeneca VRI Research Grant, the Takeda Science Foundation, and the Gout Research Foundation of Japan.

Conflict of interest The authors declare that they have no conflict of interest.

Open Access This article is distributed under the terms of the Creative Commons Attribution License which permits any use, distribution, and reproduction in any medium, provided the original author(s) and the source are credited.

\section{References}

1. Kamatani Y, Matsuda K, Okada Y, Kubo M, Hosono N, Daigo Y, Nakamura Y, Kamatani N (2010) Genome-wide association study of hematological and biochemical traits in a Japanese population. Nat Genet 42(3):210-215

2. Mii A, Nakajima T, Fujita Y, Iino Y, Kamimura K, Bujo H, Saito Y, Emi M, Katayama Y (2007) Genetic association of low-density lipoprotein receptor-related protein 2 (LRP2) with plasma lipid levels. J Atheroscler Thromb 14(6):310-316

3. Wang LL, Pan XL, Wang Y, Tang HD, Deng YL, Ren RJ, Xu W, Ma JF, Wang G, Chen SD (2011) A single nucleotide polymorphism in LRP2 is associated with susceptibility to Alzheimer's disease in the Chinese population. Clin Chim Acta 412(3-4):268-270

4. Wallace SL, Robinson H, Masi AT, Decker JL, McCarty DJ, Yu TF (1977) Preliminary criteria for the classification of the acute arthritis of primary gout. Arthritis Rheum 20(3):895-900

5. Hamajima N, J-MICC Study Group (2007) The Japan MultiInstitutional Collaborative Cohort Study (J-MICC Study) to detect gene-environment interactions for cancer. Asian Pac J Cancer Prev 8(2):317-323

6. Matsuo H, Kamakura K, Saito M, Okano M, Nagase T, Tadano Y, Kaida K, Hirata A, Miyamoto N, Masaki T, Nakamura R, Motoyoshi K, Tanaka H, Tsuji S (1999) Familial paroxysmal dystonic choreoathetosis: clinical findings in a large Japanese family and genetic linkage to 2q. Arch Neurol 56(6):721-726

7. Margraf RL, Mao R, Wittwer CT (2008) Rapid diagnosis of MEN2B using unlabeled probe melting analysis and the LightCycler 480 instrument. J Mol Diagn 10(2):123-128

8. Matsuo H, Kamakura K, Matsushita S, Ohmori T, Okano M, Tadano Y, Tsuji S, Higuchi S (1999) Mutational analysis of the anion exchanger 3 gene in familial paroxysmal dystonic choreoathetosis linked to chromosome 2q. Am J Med Genet 88(6):733-737

9. Dehghan A, Köttgen A, Yang Q, Hwang SJ, Kao WL, Rivadeneira F, Boerwinkle E, Levy D, Hofman A, Astor BC, Benjamin EJ, van Duijn CM, Witteman JC, Coresh J, Fox CS (2008) Association of three genetic loci with uric acid concentration and risk of gout: a genome-wide association study. Lancet 372(9654):1953-1961

10. Kolz M, Johnson T, Sanna S, Teumer A, Vitart V, Perola M, Mangino M, Albrecht E, Wallace C, Farrall M, Johansson A, Nyholt DR, Aulchenko Y, Beckmann JS, Bergmann S, Bochud M, Brown M, Campbell H, Connell J, Dominiczak A, Homuth G, Lamina C, McCarthy MI, Meitinger T, Mooser V, Munroe P, Nauck M, Peden J, Prokisch H, Salo P, Salomaa V, Samani NJ, Schlessinger D, Uda M, Volker U, Waeber G, Waterworth D, Wang-Sattler R, Wright AF, Adamski J, Whitfield JB, Gyllensten U, Wilson JF, 
Rudan I, Pramstaller P, Watkins H, Doering A, Wichmann HE, Spector TD, Peltonen L, Volzke H, Nagaraja R, Vollenweider P, Caulfield M, Illig T, Gieger C (2009) Meta-analysis of 28,141 individuals identifies common variants within five new loci that influence uric acid concentrations. PLoS Genet 5(6):e1000504

11. Matsuo H, Chiba T, Nagamori S, Nakayama A, Domoto H, Phetdee K, Wiriyasermkul P, Kikuchi Y, Oda T, Nishiyama J, Nakamura T, Morimoto Y, Kamakura K, Sakurai Y, Nonoyama S, Kanai Y, Shinomiya N (2008) Mutations in glucose transporter 9 gene SLC2A9 cause renal hypouricemia. Am J Hum Genet 83(6):744-751

12. Dinour D, Gray NK, Campbell S, Shu X, Sawyer L, Richardson W, Rechavi G, Amariglio N, Ganon L, Sela BA, Bahat H, Goldman M, Weissgarten J, Millar MR, Wright AF, Holtzman EJ (2010) Homozygous SLC2A9 mutations cause severe renal hypouricemia. J Am Soc Nephrol 21(1):64-72

13. Woodward OM, Köttgen A, Coresh J, Boerwinkle E, Guggino WB, Köttgen M (2009) Identification of a urate transporter, ABCG2, with a common functional polymorphism causing gout. Proc Natl Acad Sci USA 106(25):10338-10342

14. Matsuo H, Takada T, Ichida K, Nakamura T, Nakayama A, Ikebuchi Y, Ito K, Kusanagi Y, Chiba T, Tadokoro S, Takada Y, Oikawa Y, Inoue H, Suzuki K, Okada R, Nishiyama J, Domoto H, Watanabe S, Fujita M, Morimoto Y, Naito M, Nishio K, Hishida A, Wakai K, Asai Y, Niwa K, Kamakura K, Nonoyama S, Sakurai Y, Hosoya T, Kanai Y, Suzuki H, Hamajima N, Shinomiya N (2009) Common defects of ABCG2, a high-capacity urate exporter, cause gout: a function-based genetic analysis in a Japanese population. Sci Transl Med 1(5):5ra11

15. Ichida K, Matsuo H, Takada T, Nakayama A, Murakami K, Shimizu T, Yamanashi Y, Kasuga H, Nakashima H, Nakamura T, Takada Y, Kawamura Y, Inoue H, Okada C, Utsumi Y, Ikebuchi Y, Ito K, Nakamura M, Shinohara Y, Hosoyamada M, Sakurai Y, Shinomiya N, Hosoya T, Suzuki H (2012) Decreased extra-renal urate excretion is a common cause of hyperuricemia. Nat Commun 3:764

16. Matsuo $H$, Ichida $K$, Takada $T$, Nakayama A, Nakashima $H$, Nakamura T, Kawamura Y, Takada Y, Yamamoto K, Inoue H, Oikawa Y, Naito M, Hishida A, Wakai K, Okada C, Shimizu S, Sakiyama M, Chiba T, Ogata H, Niwa K, Hosoyamada M,
Mori A, Hamajima N, Suzuki H, Kanai Y, Sakurai Y, Hosoya T, Shimizu T, Shinomiya N (2013) Common dysfunctional variants in ABCG2 are a major cause of early-onset gout. Sci Rep 3:2014

17. Urano W, Taniguchi A, Anzai N, Inoue E, Kanai Y, Yamanaka M, Endou H, Kamatani N, Yamanaka H (2010) Sodium-dependent phosphate cotransporter type 1 sequence polymorphisms in male patients with gout. Ann Rheum Dis 69(6):1232-1234

18. Nakayama A, Matsuo H, Shimizu T, Ogata H, Takada Y, Nakashima H, Nakamura T, Shimizu S, Chiba T, Sakiyama M, Ushiyama C, Takada T, Inoue K, Kawai S, Hishida A, Wakai K, Hamajima N, Ichida K, Sakurai Y, Kato Y, Shinomiya N (2013) A common missense variant of monocarboxylate transporter 9 (MCT9/SLC16A9) gene is associated with renal overload gout, but not with all gout susceptibility. Hum Cell 26(4):133-136

19. Sakiyama M, Matsuo H, Shimizu S, Nakashima H, Nakayama A, Chiba T, Naito M, Takada T, Suzuki H, Hamajima N, Ichida K, Shimizu T, Shinomiya N (2013) A common variant of organic anion transporter 4 (OAT4/SLC22A11) gene is associated with renal underexcretion type gout. Drug Metab Pharmacokinet [Epub ahead of print]

20. Orlando RA, Rader K, Authier F, Yamazaki H, Posner BI, Bergeron JJ, Farquhar MG (1998) Megalin is an endocytic receptor for insulin. J Am Soc Nephrol 9(10):1759-1766

21. Willnow TE, Goldstein JL, Orth K, Brown MS, Herz J (1992) Low density lipoprotein receptor-related protein and gp330 bind similar ligands, including plasminogen activator-inhibitor complexes and lactoferrin, an inhibitor of chylomicron remnant clearance. J Biol Chem 267(36):26172-26180

22. Borgaonkar DS, Schmidt LC, Martin SE, Kanzer MD, Edelsohn L, Growdon J, Farrer LA (1993) Linkage of late-onset Alzheimer's disease with apolipoprotein E type 4 on chromosome 19. Lancet 342(8871):625

23. Corder EH, Saunders AM, Strittmatter WJ, Schmechel DE, Gaskell PC, Small GW, Roses AD, Haines JL, Pericak-Vance MA (1993) Gene dose of apolipoprotein E type 4 allele and the risk of Alzheimer's disease in late onset families. Science 261(5123):921-923

24. Marzolo MP, Farfan P (2011) New insights into the roles of megalin/LRP2 and the regulation of its functional expression. Biol Res 44(1):89-105 